\title{
EFFECTS OF A SAFFRON ALCOHOLIC EXTRACT ON VISUAL SHORT-TERM MEMORY IN HUMANS: A PSYCHOPHYSICAL STUDY
}

\author{
Received February 6, 2014.
}

The effects of an extract from saffron (Crocus sativus L.) on visual short-term memory (STM) were examined in 20 volunteers. The extract was obtained from saffron petals using $100 \%$ ethylic alcohol, concentrated by vacuum evaporation, dried, and encapsulated (30 mg per capsula). Ten participants received the extract each day for three weeks, while other 10 subjects received encapsulated placebo. Then, the contrast sensitivity of a subject was estimated; sinusoidal grating patches with different contrast levels $(0-100 \%)$ were used (experiment 1). In experiment 2, the retention of STM was assessed in two-force choice tests, using a delayed match to sample paradigm. In experiment 3 , the $n$-back memory test with different interstimulus intervals (up to $14 \mathrm{sec}$ ) was used. It was found that subjects after medication with the saffron extract demonstrated better correct memorizing of the preceding visual stimuli (from two to five). At the same time, extract medication somewhat improved retention of visual STM, but only for several intermediate interstimulus intervals, and the effect was not very remarkable. Our findings buphasize the expedience to research of the effects of physiologically active dietary constituents in humans.

Keywords: saffron; short-term memory, visual memory, contrast sensitivity test, delayed match to a sample paradigm, $n$-back memory test.

\section{INTRODUCTION}

Memory is one of the most crucial human capabilities; its impairments can cause serious health problems. Generally, human memory is divided into two types, short-term memory (STM), allowing one to recall for a period of several seconds up to $1 \mathrm{~min}$ without rehearsal, and long-term memory (LTM) able to store much larger amounts of information for a potentially unlimited duration [1 - 3]. Information, after a short time, is transmitted from STM to LTM $[4,5]$. Therefore, impairments of STM can cause different problems for LTM. Thus, the search for ways or medications that can improve STM has long been considered.

The effects of dieting or different dietary substances on cognitive functions and memory configuration were studied by many researchers [6, 7]. "Everyday" or frequently consumed food may contain some neurochemically active substances. Studies on

\footnotetext{
${ }^{1}$ Neuroscience Research Center, Baqiyatallah (a.s.), University of Medical Sciences, Tehran, Iran.

${ }^{2}$ Electrical Engineering Faculty, Garmsar Branch of the Islamic Azad University, Garmsar, Iran.

Correspondence should be addressed to G. H. Meftahi

(e-mail: meftahi208@yahoo.com or hosein.meftahi@gmail.com).
}

laboratory animals showed that certain foods and lowcalorie diets are beneficial for cognitive functions [8 - 11]. These facts showed a direct relationship between characteristics of food and brain functions. The number of studies of the effects of nutrients on brain functions in humans are, however, much fewer than those using animal models despite examination of the respective effects of agents present in "everyday"consumed human diets is quite expedient.

In our study, we assessed the effect of a saffron (Crocus sativus L.) extract on human STM considering that little is known about the respective effects. Saffron has been extensively used as a spice in cooking and, since ancient times, in traditional medicine as an herbal remedy with different effects $[12,13]$. Bitter taste of saffron is due to the presence of a substance called picrocrocin. This substance, during processing of a fresh plant due to thermal or enzymatic decomposition, is converted in to aromatic aldehyde named safranal. Crocin is responsible for the color of saffron. Crocin itself consists of glycosides that contain a carotenoid (called crocetin) and sugars. [14].

As was mentioned, the configuration of LTM is built after information has been transmitted from STM. 
There exists a crucial issue whether some type of herbal remedy (alcoholic saffron extract, ASE, in our case) can boost STM or not? The positive outcome of the hypothesis will prove the result of pioneer studies, which indicated positive effects of food and diet on improvements of STM indirectly. In our study, we evaluated the effect of ASE on two aspects of visual ATM, the retention and the capacity of this type of memory.

\section{METHODS}

Examined Group. Twenty volunteer participants participated in our psychophysical texts. These subjects were enrolled and randomized, considering their ages, in two identical groups, 10 subjects in each. The first group received placebo, while the second group received ASE (both encapsulated). Before such medication, all subjects participated in visual STM tests. Then, all subjects received their medications, either placebo or ASE, for three weeks in a highly regular double-blind manner. The test taker did not know anything about the type of medications that subjects received. After this period, all psychophysical experiments were repeated in both groups. Each experiment (estimation of the contrast sensitivity and evaluation of the retention and capacity of STM) lasted about $40 \mathrm{~min}$, and the duration of a complete experiment for one person was 2-2.5 h.

Preparation of ASE. Dried petal saffron was obtained from the botany farm of the Medicine Faculty of the Baqyiatallah (a.s.) University and sent to the laboratory of the Pharmaceutical college of the Shahid Beheshti Medicine University (Tehran, Iran). Saffron was powdered, and $100 \mathrm{~g}$ of the powder was extracted using $100 \%$ ethylic alcohol. The extract was separated, filtered through Watman paper filters, concentrated by vacuum evaporation, dried at low temperatures, and encapsulated. Each capsule contained $30 \mathrm{mg}$ ASE.

Psychophysical Experiments. To assess the effect of ASE on human STM, we designed three experiments. In the first experiment, we determined the contrast sensitivity of a subject in response to presentation of sinusoidal grating patches with different contrast levels. The data obtained were taken into account in the second experiment for assessing the retention of STM. In the last experiment, we evaluated the capacity of STM using different types of stimuli. To perform the first test, a set of images (sinusoidal grating patches) with various contrast levels (from 0 to $100 \%$ ) was generated. Figure $1 \mathrm{~A}$ shows several samples of the image data set. We ran two-force choice tests. In each trial, a fixation cross appeared at the center of the screen for $1.5 \mathrm{sec}$. This long fixation time was used to remove the low-level adaptation of previously presented images. Following fixation the cross, a pair of randomly selected images was presented simultaneously for $0.8 \mathrm{sec}$ (separated by a gap of 200 pixels). The participants were seated approximately $90 \mathrm{~cm}$ from the monitor; the stimulus display subtended $27 \times 11 \mathrm{deg}$ of visual angle. Subjects were instructed to indicate if the images had the same or different contrast level by pressing one of two designated buttons on the computer keyboard ( $\mathrm{n}$ and m) and completed 420 trials each. Figure 1B shows timing of this experiment. The latter was designed using MATLAB software and Psych tool box $[15,16]$.

After obtaining the performance of all subjects for different contrast levels at this step, a sigmoid function that followed from Equation 1 was fitted to the obtained data points to attain a subjects' psychometric function. The intersection of this curve with the $50 \%$ performance was selected as an index
A

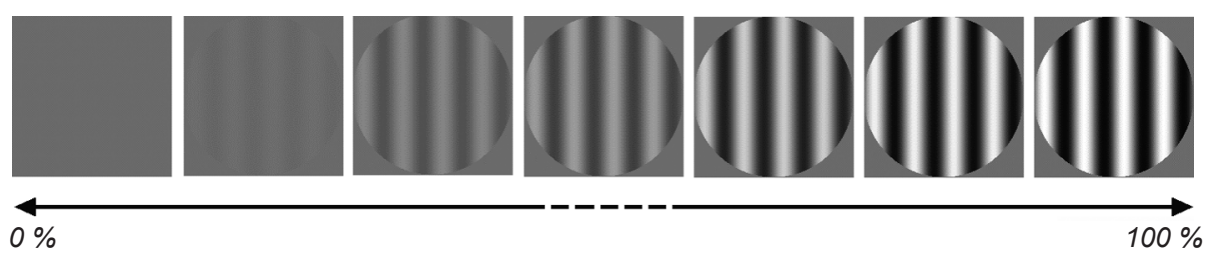

F i g. 1. Examples of sinusoidal gratings with different contrast levels presented in the tests (A), and scheme of the experiment procedure and timing for estimation of the contrast sensitivity of subjects (B).

Р и с. 1. Приклади синусоїдальних решіток з різними рівнями контрасту, застосованих у тестах $(A)$, та схема експериментальної процедури для оцінки контрастної чутливості тестованих $(B)$.

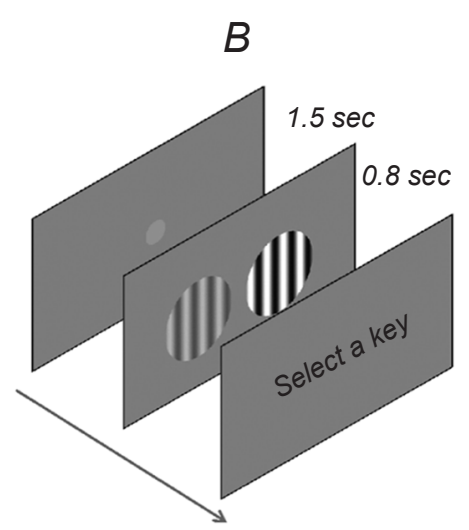


of the contrast sensitivity of each subject. This value and psychometric function of two sample subjects are represented in Fig. 2. The contrast sensitivity value here means that if we increase the contrast difference of the paired represented images above this value for a particular subject, the subject can distinguish the images more easily.

$$
f(x)=\frac{1}{1+e^{-\left(\frac{x-a}{b}\right)}}
$$

To assess the retention of STM, we used a Delayed Match to Sample (DMS) paradigm [17, 18]. After presenting a fixation cross for $1.5 \mathrm{sec}$, a visual stimulus (sinusoidal grating) appeared at the center of the computer screen for $1 \mathrm{sec}$. After a delay period (interstimulus interval, ISI), a pair of images appeared on the screen for $1 \mathrm{sec}$. Participants were asked to say which of the presented stimuli had appeared previously. Generally, to make the experiment more difficult for observers, two test stimuli should be very similar to the original response-inducing stimulus. For this purpose, two test images were displayed with a contrast difference equal to the contrast sensitivity value of each individual. Because of this, subjects required attending to the test as much as possible. As explained, after presenting the first stimulus, a blank (grey) screen was presented within the ISI. The duration of ISI was randomly sampled from 1.5 up to $14 \mathrm{sec}$ with $1.5 \mathrm{sec}-$ long steps. The selection was

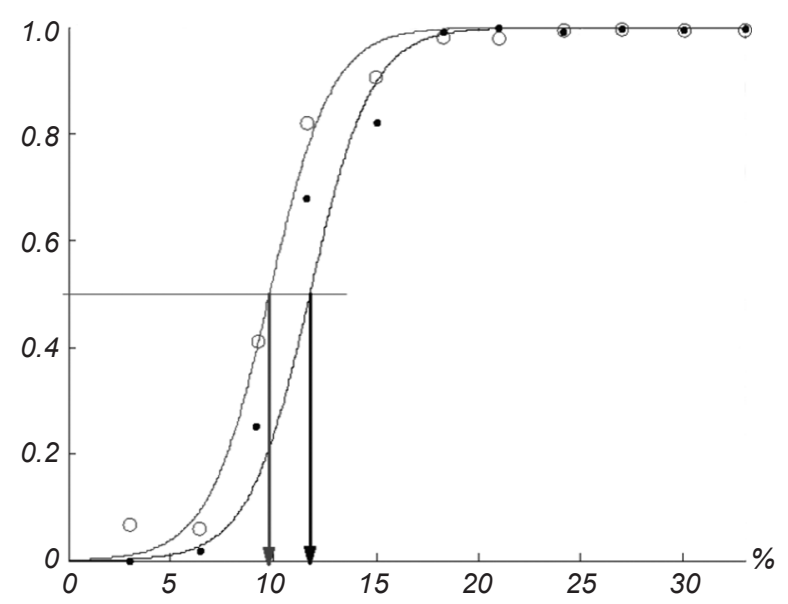

F i g. 2. Two sample psychometric functions for different contrast levels demonstrated by two participants. Intersections of the curves with the threshold line specifies the contrast sensitivity of each individual.

Р и с. 2. Два графіки психометричних функцій для різних рівнів контрасту, продемонстрованих двома тестованими. performed based on a uniform distribution; therefore, we had an equal number of each time intervals (1.5, $3.0,4.5,6.0,7.5,9.0,10.5,12.0$, and $14.0 \mathrm{sec})$. Subjects completed two blocks consisting 135 trails. They were instructed to remember the first stimulus during the ISI and then select the correct stimulus after presenting test images by pressing one of two keys ( $\mathrm{n}$ or $\mathrm{m}$ ) on the computer keyboard. Needless to say that one of the test stimuli is the previously presented image, and the contrast difference of test images is equal to the contrast sensitivity of the each participant. It should also be noted that the location of test images on the screen (right or left) in each trial was selected randomly. Therefore, subjects could not guess where the image would appear on the screen. This process was repeated for each individual, and finally the number of correct responses as a function of the time difference was considered. Figure 3 illustrates the experimental procedure.

After performing this test, the $n$-back memory test for visual STM was used [19]. The $n$-back memory test is one of the most popular experimental paradigms for studying working memory, in which subjects are asked to monitor the identity or location of a series of verbal or nonverbal stimuli and to indicate when the currently presented stimulus is the same as that presented $n$ trials earlier [20-21]. We used series of visual stimuli designed and generated using MATLAB. Some image samples from the collection are shown in Fig. 4A. On each trial, a fixation cross appeared on the screen

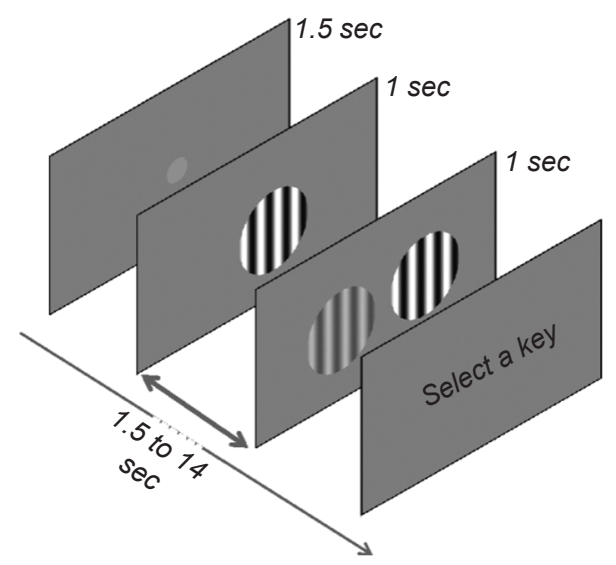

F i g. 3. Experimental procedure for the measurement of short-term memory retention and timing of image presentation. The interval between the first image and the test image presentations is randomly changed. Contrast differences between the two pictures shown side by side is equal to the contrast sensitivity of each individual.

P и с. 3. Експериментальна процедура для оцінки якості зберігання в короткочасній пам'яті та часові характеристики представлення зображень. 
F i g. 4. Examples of the images used in the test of short-term memory capacity (A) and the experimental procedure for testing this capacity and timing of image presentations (B).

P и с. 4. Приклади зображень, використаних для тестування місткості короткочасної пам'яті $(A)$, та експериментальна процедура для оцінки такої місткості $(B)$.
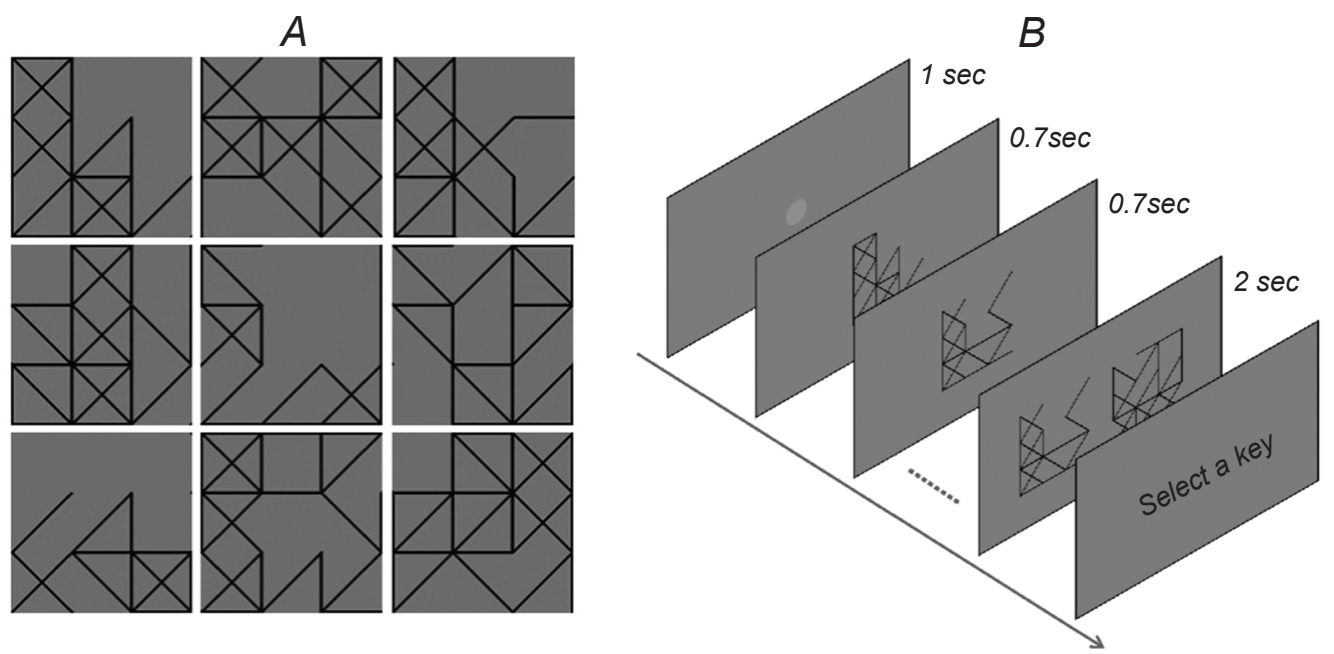

for $1 \mathrm{sec}$. Then a series of randomly selected images were shown at the center of the screen. Each image in the series was presented for $0.7 \mathrm{sec}$. Following serial presentation, two individual images were displayed, and the participant was asked to indicate which stimulus was similar to a previously shown image. The test stimuli were presented for $2 \mathrm{sec}$. Normally, subjects can remember the last penultimate and the two end stimuli. This generally indicates that the STM capacity is limited. We used these types of stimuli to eliminate the confounding effect of familiar visual stimuli and generate a novel set of stimuli, which are not very easy to memorize. It is worth mentioning that the location of test images on the screen (right or left) in each trial was selected randomly. Therefore, subjects could not guess where the image would appear on the screen. Subjects completed 60 trials for each order of

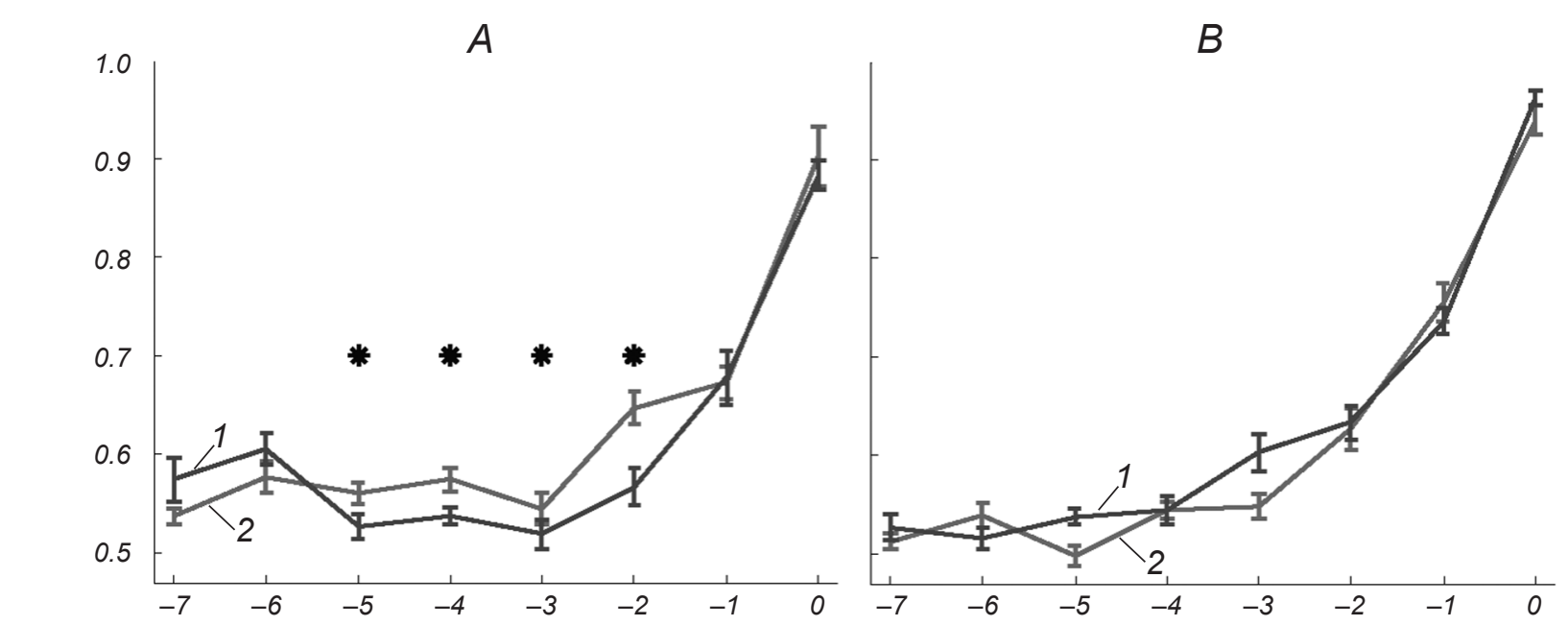

sequence (block). We continued the experiment until $n=7$ (seven end stimulus) was attained. The experiment procedure is shown in Fig. 4B.

\section{RESULTS}

According to the accessible literature, no studies have so far assessed the effect of saffron (ASE) on human STM. The main question addressed in this study is whether saffron constituents can improve human STM. In this study, we considered two properties of STM, the retention and capacity; two psychophysical experiments were designed to evaluate their characteristics.

Figure 5 demonstrates the results of the experiment for visual STM capacity ( $n$-back test). The averages

F i g. 5. Performance of participants in the experiment on short-term memory capacity. A) Performance before (1) and after (2) medication for alcoholic saffron extract recipients. B) That before (1) and after (2) medication for placebo recipients. Abscissa) Order in sequence; ordinate) normalized accuracy.

Р и с. 5. Показники учасників експериментів щодо оцінки місткості короткочасної пам’яті. 
and standard deviations for all participants in two groups, placebo and ASE, are shown in this figure. The horizontal axis shows the orders of sequence of the presented images. In other words, number 0 represents the last presented image in the series of consecutive images. Similarly, number 1 shows the penultimate presented image, number 2 indicates the two to end image, and so on. The vertical axis in Fig. 5 also shows the performance of subjects in detecting the correct stimulus (memorizing stimulus). As it was predicted by increasing the difficulty of the test, the performance of subjects dwindles. For example, in remembering the 7 th previously shown image, the performance is at chance. Figure 5B exhibits the performance of subjects who received placebo before and after medication (curve 2 shows the performance after medication, and curve 1 is for before using placebo). It can be seen that there was no significant difference in performance before and after using placebo (B). On the other hand, subjects who received ASE showed significant improvement in performing the several order of sequences, as is shown in Fig. 5A. This figure shows that the performances of subjects in remembering images in four intermediate stages are significantly different between preconsumption and post-consumption of ASE (sequences of experiments in which a significant difference exists are specified with asterisks). To test the significance of these results, the $t$-test and the Kolmogorov - Smirnov two-sample test [22] were used ( $t$-test, $P<0.003$, and Kolmogorov - Smirnov test, $P<0.006)$. There was

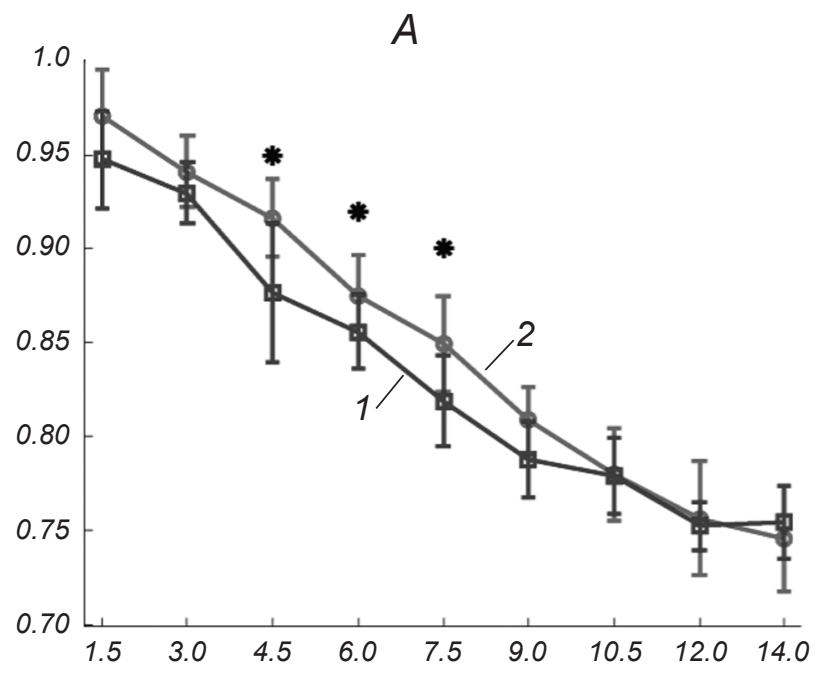

no significant difference in the results of two first stages of experiments due to the test simplicity. In other words, healthy people are able to do such tasks easily. Similarly, the lack of significant difference in the final stages of testing resulted from the high level of difficulty. In the last stages, the number of presented images in the sequence is increased, and the overall similarities between images are rather high; so, it is very difficult for a person to memorize the images in the process. Therefore, there is no significant difference in the outcomes of the before and after of medication. Based on the results, it can be stated that the use of ASE improves STM capacity, and its impact is significant.

Another experiment was conducted to evaluate the effect of ASE on the retention of visual STM. The results of this experiment are shown in Fig. 6. The horizontal axis in this figure shows time intervals between the first presented image (response image) and the test images shown after; the vertical axis also shows the performance of correct responses in remembering images. As was expected, the errors increased as the time interval between stimuli (response and test) increased. Fig. 6B shows the results of the placebo recipients before and after consumption. As is shown, there was no significant difference between before and after consumption. According to Fig. 6A, it can be concluded that the performance of subjects improved after taking ASE, but the improvement was significant only for several intermediate times marked with asterisks $(t$-test, $P<0.02$; Kolmogorov -

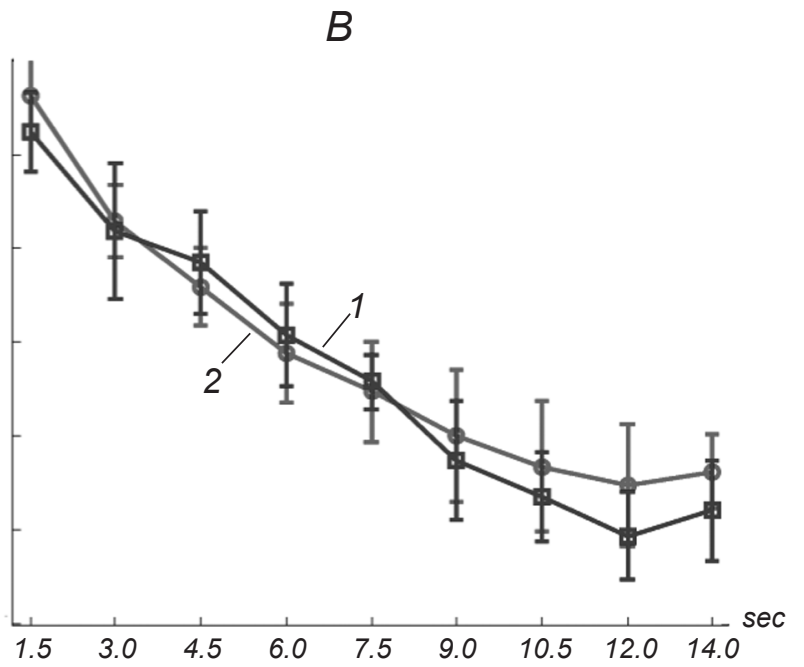

F i g. 6. Performance of participants in the experiment on short-term memory retention. A) Performance before (1) and after (2) medication for alcoholic saffron extract recipients. B) That before (1) and after (2) medication for placebo recipients. Abscissa) Time interval between presentations, sec; ordinate) normalized accuracy.

Р и с. 6. Показники учасників експериментів щодо оцінки якості збереження у короткочасній пам'яті. 
Smirnov test, $P<0.04)$. It should also be noted that the significant differences in these time intervals were not very remarkable. Figure $6 \mathrm{~A}$ indicates that the use of ASE exerted a smaller improving impact on the retention of STM compared to the capacity of the latter. These results shown in Fig. 6A are not too surprising since, based on fundamental definitions, the retention of STM is limited (approximately several seconds), and anything more is needed to be transferred to LTM. This fact also shows that improving the retention of STM is limited but is achievable to some extent.

For further analysis, the overall performance of the participants in both experiments and groups (recipients of ASE or placebo) were calculated separately to evaluate the overall effects of medication. As stated earlier, each individual participated in both experiments (the capacity and retention of STM). All experiments were repeated after medication to evaluate the effect of drugs on this type of memory. Therefore, each individual has a performance before and after medication. The average performance of each subject in two tests was calculated in this step. This was done to find an overall relationship between ASE effects and memory. Figure 7A demonstrates the results of subjects who received ASE (before and after using). In this figure, each dot represents a person participating in the experiment; the horizontal axis represents the performance before, while the vertical axis represents the performance after medication. Hence, any point shows two numbers, one performance before and another after medication. As is clear from Fig. 7A, the overall performance of subjects who received ASE is better than that in the group receiving placebo. The performances of placebo recipients (Fig. 7B) are around the mid-line and did not change significantly before and after medication. However, most ASE recipients are located in the area above mid-line (the top-left) after medication (Fig. 7A).

Thus, the effects of ASE on visual STM was assessed. Different studies have investigated the effects of food type and various food diets on memory. Most of these studies have been conducted on laboratory animals; therefore, generalizing of these results on human needs further research. In our study, we used visual psychophysics to directly evaluate such an effect in humans. This allows us to explore the direct relationship between the remedy used and human STM. To our knowledge, no studies have so far assessed the effects of ASE on human STM. The results of our study point out that ASE provides a significant impact in on STM noticeably improving the STM capacity. However, it exerts smaller, in general, improving effects on memory retention.

One of the reasons that can cause problems in memory and remembering the events is stress and tension. Stress significantly affects some of the cognitive processes in the brain. One of the characteristics of the constituents of saffron is smoothing of stress. So, it is possible that the improvement of STM is one of the effects of indirect factors in a complex of changes provided by a dietary constituent (saffron) and directed toward reduction of
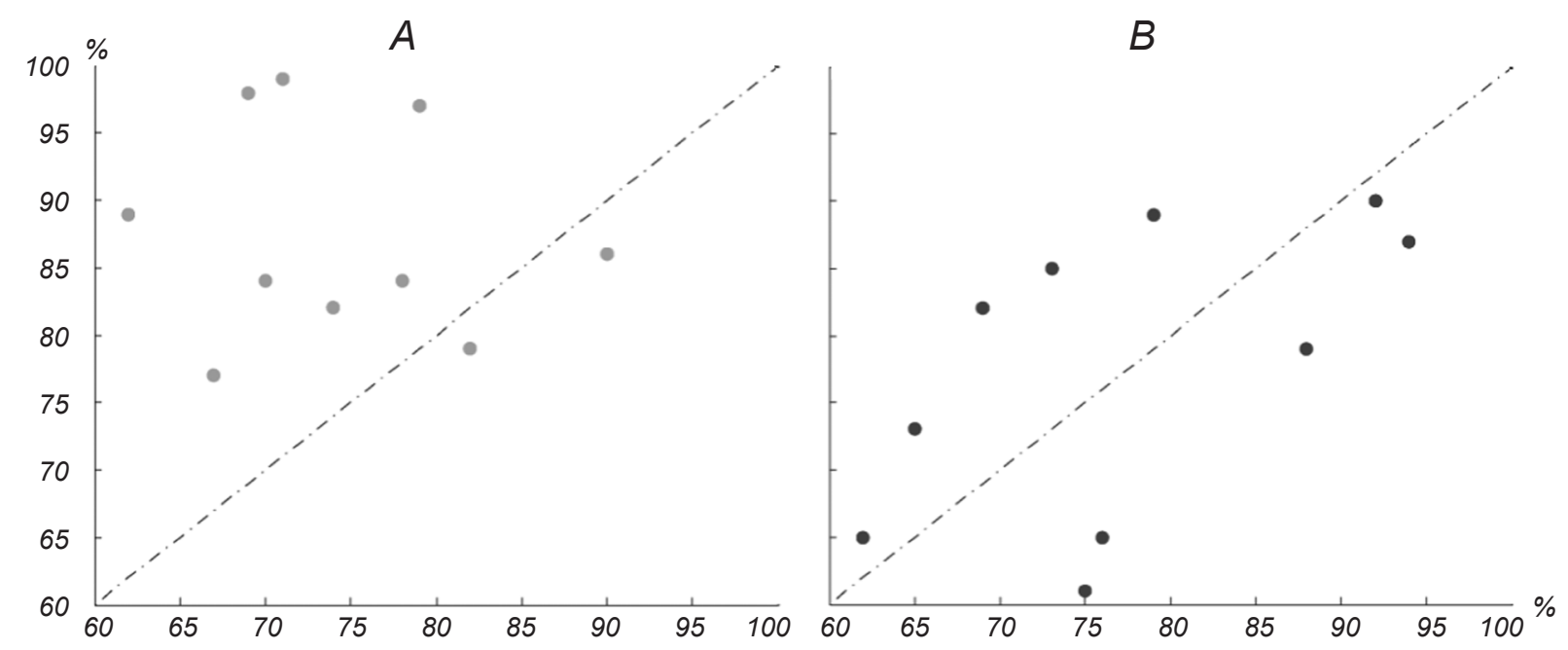

Fi g. 7. Correlation fields for the joint performance in two tests of short-term memory capacity and retention for recipients of alcoholic saffron extract (A) and for placebo recipients (B). Each dot represents a subject. Abscissa) Performance before, ordinate) that after medication, \%.

Р и с. 7. Кореляційні поля об'єднаних результатів двох тестів щодо місткості короткочасної пам'яті та якості зберігання в ній для учасників, котрі отримували алкогольний екстракт шафрану $(A)$, та для тих, хто отримував плацебо $(B)$. 
the stress level. Our findings emphasize the expedience of research of the effects of the respective constituents in humans.

Acknowledgments. This work was supported by a grant from Neuroscience Research Center, Baqiyatallah (a.s.) University of Medical Sciences.

The experiments reported here were in accordance with international standard ethical guidelines and approved by the local Ethical committee (the Baqiyatallah (a.s.) University of Medical Committee), Tehran, Iran. All participants gave their written consent for their involvement in the tests.

The authors, M. Ghodrat, H. Sahraei, J. Razjouyan, and G. H. Meftahi, have no conflict of interest.

\section{М. Гходрат ${ }^{1}$, Х. Сахраєї, Дж. Разджоуян ${ }^{2}$, Г. Х. Мефтахі}

ВПЛИВИ АЛКОГОЛЬНОГО ЕКСТРАКТУ ШАФРАНУ НА ЗОРОВУ КОРОТКОЧАСНУ ПАМ'ЯТЬ ЛЮДИНИ: ПСИХОФІЗИЧНЕ ДОСЛІДЖЕННЯ

${ }^{1}$ Дослідний центр нейронаук Бакійяталлах Медичного
університету, Тегеран (Іран).
${ }^{2}$ Гамсарське відділення Ісламського університету Азад
(Іран).

P е 3 ю м е

На групі з 20 добровольців досліджували впливи екстракту шафрану (Crocus sativus L.) на візуальну короткочасну пам'ять (КЧП). Екстракт отримували 3 пелюсток шафрану, використовуючи 100 \%-вий етиловий спирт, концентрували за допомогою випаровування під вакуумом, висушували та капсулювали (30 мг у капсулі). 10 учасників приймали екстракт один раз на добу протягом трьох тижнів, тоді як інші 10 тестованих отримували плацебо (також у капсулах). В експерименті 1 визначали контрастну чутливість кожного випробуваного. Використовували зображення решіток із ліній, контраст яких змінювався за синусоїдальним законом; контрастність пред'явлених зображень варіювали від 0 до 100 \%. В експерименті 2 оцінювали ємність КЧП випробуваних у тестах дворівневого вибору, застосовуючи парадигму відтермінованої оцінки збігу зі зразком. В експерименті 3 використовували $n$-зворотний тест збереження пам'ятного сліду при різних інтервалах між візуальними стимулами (до 14 с). Після курсового приймання екстракту шафрану тестовані демонстрували кращий рівень коректного запам'ятовування двох-п'яти попередніх візуальних стимулів. У той же час позитивний вплив екстракту на збереження зорових слідів у КЧП хоч і проявлявся, проте лише для деяких проміжних міжстимульних інтервалів, і він був менш значним. Наші спостереження підкреслюють доцільність дослідження ефектів фізіологічно активних компонентів, які входять до складу продуктів харчування.

\section{REFERENCES}

1. J. Xu, V. D. Calhoun, G. D. Pearlson, and M. N. Potenza, "Opposite modulation of brain functional networks implicated at low vs. high demand of attention and working memory," PLoS One, 31, No. 9 (1) (2014).

2. A. K. Barbey, M. Koenigs, and J. Grafman, "Orbitofrontal contribution to human working memory," Cerebr. Cortex, 21, 789-795 (2011).

3. R. Sala-Llonch, C. Pena-Gomez, E. M. Arenaza-Urquijo, et al., "Brain connectivity during resting state and subsequent working memory task predicts behavioural performance," Cortex, 48, 1187-1196 (2012).

4. J. R. Jonides, D. E. Lewis, C. A. Nee, et al., "The mind and brain of short-term memory," Annu. Rev. Psychol., 59, 193-224 (2008)

5. Y. Yang and N. Calakos, "Presynaptic long-term plasticity," Front Synapt. Neurosci., 17, No. 5, 8 (2013).

6. K. Oberauer and R. A. Kliegl, "Formal model of capacity limits in working memory," J. Mem. Lang., 55, No. 4, 601-626 (2006).

7. C. Berr, F. Portet, I. Carriere, et al., "Olive oil and cognition: results from the three-city study," Dement. Geriat. Cogn. Disord., 28, No. 4, 357-364 (2009).

8. A. Nilsson, J. Tovar, M. Johansson, et al., "A diet based on multiple functional concepts improves cognitive performance in healthy subjects," Nutr. Metab., 15, No. 10 (1), 49 (2013).

9. L. Deng, Z. N. Wu, and P. Z. Han, "Effects of different levels of food restriction on passive-avoidance memory and the expression of synapsin I in young mice," Int. J. Neurosci., 119, No. 2, 291-304 (2009).

10. T. Hashimoto and S. Watanabe, "Chronic food restriction enhances memory in mice-analysis with matched drive levels," NeuroReport, 16, No. 10, 1129-1133 (2005).

11. I. G. Newton, M. E. Forbes, C. Legault, et al., "Caloric restriction does not reverse aging-related changes in hippocampal BDNF," Neurobiol. Aging, 26, No. 5, 683-688 (2005)

12. M. C. Roberge, J. Hotte-Bernard, C. Messier, and H. Plamondon, "Food restriction attenuates ischemia-induced spatial learning and memory deficits despite extensive CA1 ischemic injury," Behav. Brain Res., 187, No. 1, 123-132 (2008).

13. S. Akhondzadeh, N. A. Tahmacebi-Pour, H. Noorbala, et al., "Crocus sativus $L$. in the treatment of mild to moderate depression: a double-blind, randomized and placebo-controlled trial," Phytother. Res., 19, No. 2, 148-151 (2005).

14. S. Kianbakht and A. Ghazavi, "Evaluation of immunological and hematological effects of saffron in men," Ethnopharmacologia, 36, 78 (2005).

15. M. Liakopoulou-Kyriakides and D. A. Kyriakidis, "Croscus sativus - biological active constitutents," Stud. Nat. Prod. Chem., 26, 293-312 (2002).

16. D. H. Brainard, "The psychophysics toolbox," Spat. Vis., 10, No. 4, 433-436.

17. M. Kleiner, D. Brainard, A. Pelli, et al., "What's new in Psychtoolbox-3," Perception, 36, (2007).

18. P. Harnett, D. McCarthy, and M. Davison, "Delayed signal detection, differential reinforcement and short term memory in the pigeon," J. Exp. Anal. Behav., 42, 87-111 (1984).

19. D. McCarthy and P. Voss, "Delayed matching to sample performance: effects of relative reinforce frequency and of 
signal adverse unsigned reinforces magnitudes," J. Exp. Anal. Behav., 63, 33-51 (1995).

20. W. K. Kirchner, "Age differences in short-term retention of rapidly changing information," J. Exp. Psychol., 55, 352-358 (1958).
21. M. S. Gazzaniga, "Cognitive neuroscience," Concise Introd., 2 (2010).

22. F. J. Massey, "The Kolmogorov-Smirnov test for goodness of fit,” J. Am. Stat. Assoc., 46, No. 253, 68-78 (1951). 